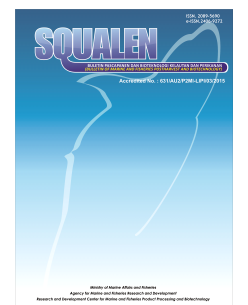

www.bbp4b.litbang.kkp.go.id/squalen-bulletin

\title{
CYTOTOXIC ACTIVITY AND SECONDARY METABOLITE CHARACTERISTICS OF SEA CUCUMBER Actinopyga sp. METHANOLIC EXTRACT
}

\author{
Muhammad Nursid ${ }^{1 *}$, Afrilia Putri Maharani ${ }^{2}$, Riyanti ${ }^{2}$, and Endar Marraskuranto ${ }^{1}$ \\ ${ }^{1}$ Research and Development Center for Marine and Fisheries Product Competitiveness and Biotechnology, \\ Jalan KS. Tubun Petamburan VI, Slipi, Central Jakarta 10260, Indonesia \\ 2) Faculty of Fisheries and Marine Science, Jenderal Soedirman University, JI. Dr. Suparno, Purwokerto 53123, Indonesia \\ Article history: \\ Received: 12 February 2016; Revised: 31 March 2016; Accepted: 27 April 2016
}

\begin{abstract}
Sea cucumber is known as the source of bioactive secondary metabolites. Actinopyga is one of the sea cucumbers that have not been explored for its bioactivity. The objectives of this research were to assess the cytotoxic activity and to examine the characteristic of sea cucumber Actinopyga sp. methanolic extract. Cytotoxicity assay was conducted by using MTT method against WiDr (colon cancer) and T47D (breast cancer) cell lines. Actinopyga sp. methanolic extract was characterized by using phytochemical screening, fourier transform-infra red spectroscopy (FT-IR), and Liquid Chromatography lon Trap Time of Flight Mass Spectrophotometer (LC-IT-ToF-MS). Results showed that Actinopyga sp. methanolic extract inhibit WiDr and T47D cell lines viability with the LC $_{50}$ value of 55.93 and $87.55 \mu \mathrm{g} /$ $\mathrm{ml}$, respectively. Functional groups analysis showed the presence of hydroxyl, amine, carboxylic acid, nitrate, amide, sulphur, ester, and ether. The spectra mass analysis of crude extract showed that it contains steroid compounds.
\end{abstract}

Keywords: Actinopyga sp., secondary metabolite, cytotoxic, WiDr, T47D

\section{Introduction}

Indonesia is rich in marine biodiversity. This biodiversity is an important source of lead chemicals for medicinal use. These secondary metabolites chemicals are usually found in marine invertebrates (Butler, 2004; Jain et al., 2008; Soltani et al., 2014).

In ecological perspective, these secondary metabolites are produced by marine invertebrate as their response to harsh marine environment to protect themselves from predator and to fight for food, space, and other environment stressors (Bordbar et al., 2011). In the last ten years, secondary metabolites that are considered as lead compounds have been developed into risk-reducing chronic disease medicine (Webb, 2006; Shahidi, 2009; Bordbar et al., 2011). Sea cucumber is considered as one of marine invertebrates that have the diversity of secondary metabolites (Leal et al., 2012).

Sea cucumber was used as traditional medicine by the Chinese and Malaysian to treat hypertension and cancer (Bahrami et al., 2014; Elbandy et al., 2014; Soltani et al., 2014). Its biological activities include antioxidant, anti-microbe, and anticancer (Liu et al., 2012; Slichenko et al., 2012; Salazar et al., 2013). It is known as the source of chemicals, such as phenol and glycoside triterpene (saponin). Januar et al. (2014) found that ethanolic extract of Holothuria sp. from South Lampung had cytotoxicity against MCF-7 cells with $L_{50}$ value of $10.32 \mu \mathrm{g} / \mathrm{ml}$. Based on the NMR and GC-FID analysis, the active compound was identified as stearic acid. Chemical composition and fatty acid analysis of Bohadschia argus, Holothuriafuscogilva, Thelenota ananas, and Actinophyga lecanora taken from Halmahera, North Maluku was investigated by Fawzya et al. (2014). Sea cucumber Bohadschia argus and B. mamorata collected from Karimunjawa waters, Central Java, showed promising actibacterial activity against Pseudomonas sp and Staphylococcus aureus (Pringganies, 2013). Actinopyga is a type of sea cucumbers that has not been explored for its

*Corresponding author.

E-mail: mnursid@kkp.go.id 
bioprospective. One study revealed that sea cucumber Actinopyga agassizi shows cytotoxic activity against bone cancer (Bhakuni and Rawat, 2005). Another also revealed that $A$. miliaris shows bioactivity against a brine shrimp species of Artemia salina (Albuntana et al., 2011).

Cancer is considered as the number one causing the death in the world. Cancer cases were raising from 12.7 million cases in 2008 to 14.1 million cases in 2012. The most frequent cases of cancer are breast and colon cancer. In Indonesia, breast cancer is the highest type of cancer case suffered to women, while colon cancer is a frequent cancer case suffered to both men and women (KEMENKES RI, 2014). Reports mentioned that colon cancer is the third most frequent cancer case in the world (WCRF, 2012). Studies have been conducted to cope with these cancer types, including exploring natural products as anticancer lead compound (Blunden, 2001; Chatterji et al., 2010; Murti \& Agrawal, 2010; Bordbar et al., 2011; Wijesinghe et al., 2013). Cancer cell lines, such as WiDr (colon cancer) and T47D (breast cancer), are frequently used as the model in in vitro biodiscovery test of natural compound. The objective of this study is to identify the characteristics of sea cucumber Actinopyga sp. methanolic crude extract and to assess its cytotoxic activity against WiDr and T47D cell lines.

\section{Material and Methods}

\subsection{Materials and Instrumentation}

The sea cucumber was taken from Pesawaran Waters, Lampung, Sumatera in June 2015. The chemicals used were analytical grade and HPLC grade. Some materials used in this study include methanol, acetonitrile, MTT [3-\{4,5-dimetilthiazol-2yl)2,5-difenil tetrazolium bromide], colon cancer cell line (WiDr), breast cancer cell line (T47D), Rosewell Park Memorial Institute (RPMI) medium, and Fetal Bovine Serum (FBS). Some instrumentations used in this study include vacuum rotavapour (Buchi), Fourier Transform-Infra Red Spectroscopy (FT-IR) (Perkin Elmer), Liquid Chromatography lon Trap Time of Flight Mass Spectrophotometer (LC-IT-ToF-MS) (Shimadzu), inverted microscope (Olympus), $\mathrm{CO}_{2}$ incubator (Esco) and microplate reader (Thermo).

\subsubsection{Sea cucumber identification and sample preparation}

The sea cucumber used in this study was confirmed by the Research Center for Oceanography, Indonesia Institute of Science (LIPI) as Actinopyga sp., or teripang kelapa (local name). It was taken by hand in 1 - 5 meter depth. Samples were washed and their entrails were cleaned. Samples were preserved cold using ice cubes and were stored in a cool box upon subsequent analysis in the laboratory.

Sample preparation began with fresh water cleaning to get rid of debris from its body surface. Then, it was cut into approximately $\pm 2 \mathrm{~cm}^{3}$ size. These sample pieces were macerated in methanol absolute for 12 hours in triplicate. Subsequently, the solution was filtered using filter paper. Filtrate was evaporated using vacuum rotary evaporator to obtain paste, and then the paste was dried using freeze dryer. The crude extract obtained was stored at $4{ }^{\circ} \mathrm{C}$ upon subsequent analysis.

\subsubsection{Functional group analysis}

Functional group analysis was conducted using Fourier Transform-Infra Red Spectroscopy (FT-IR) (Perkin Elmer). Analysis was done according to Rakesh et al. (2014) with some modifications. One mg sea cucumber Actinopyga sp. crude extract was mixed with $200 \mathrm{mg}$ of one-day oven-dried potassium bromide $(\mathrm{KBr})$ to make a pellet. The sample pellet was read with wavenumber of $450-4000 \mathrm{~cm}^{-1}$ and was scanned for 45 times. The resulted peak showed vibration value that implies functional group of compound contained in the methanolic extract of Actinopyga sp.

\subsubsection{Mass spectrometry analysis}

Liquid Chromatography Ion Trap Time of Flight Mass Spectrophotometer (LC-IT-ToF-MS) (Shimadzu) was used to analyze methanolic crude extract. Peaks were detected by Shimadzu photodiode array (PDA) detector. Chromatography was carried out on a $2.0 \mathrm{x}$ $100 \mathrm{~mm}$ Phenomenex Luna $\mathrm{C}_{18}$ column (5- $\mu \mathrm{m}$ particle size). Prior to the injection, a $5 \mathrm{mg}$ crude extract sample was cleaned up using a $0.5 \mathrm{~cm} \times 2.0 \mathrm{~mm} \mathrm{C} \mathrm{C}_{18}$ flash column. The sample was diluted in HPLC grade methanol. The filtrate obtained was filtered using a $0.45-\mathrm{mm}$ filter and was concentrated under nitrogen gas flow. The cleaned sample was injected using Shimadzu automated sampler and was eluted using gradient system of water-acetonitrile (20-100\% water) for 30 minutes.

\subsubsection{Cytotoxicity against cancer cell line}

Cytotoxic test was performed using MTT [3-\{4,5dimetilthiazol-2yl)-2,5-difenil tetrazolium bromide] method according Ebada et al. (2008) with some modifications. Breast cancer (T47D) and colon cancer (WiDr) cancer cell lines were used. Both cells were maintained in $\mathrm{CO}_{2}$ incubator (Esco) using Rosewell 
Park Memorial Institute (RPMI) media, which was supplemented with 10\% Fetal Bovine Serum (FBS) and penicillin-streptomycin. In brief, cytotoxic test was performed as follows: T47D and WiDr cells were put in a 96-well microplate at $1 \times 10^{4}$ cells/well density. After 10 hours, sample solution was added to make up a dose of 10, 30, 70, 110 and $150 \mu \mathrm{g} / \mathrm{ml}$. Doxorubicin was used as positive control at the dose of $0.0375 ; 0.075 ; 0.15 ; 0.3$, and $0.6 \mu \mathrm{g} / \mathrm{ml}$. Incubation was done for 24 hours in a $\mathrm{CO}_{2}$ incubator. After 24 hours, MTT (MTT concentration of $0.5 \mathrm{mg} / \mathrm{ml}$ ) was added into the microplate at $100 \mathrm{ml} /$ well. After 4 hours, the reaction between the cell and MTT was terminated by adding $10 \%$ SDS. The microplate was incubated at $27-30{ }^{\circ} \mathrm{C}$ for at least 10 hours. The absorbance value was measured using thermo microplate reader at the wavelength of $570 \mathrm{~nm}$. The value was used to calculate the percentage of cell mortality, and then to determine inhibition concentration-50 $\left(\mathrm{LC}_{50}\right)$ value using probit analysis.

\section{Results and Discussion}

\subsection{Extraction}

As much as $5.77 \mathrm{~g}$ of methanolic crude extract was obtained from $443.2 \mathrm{~g}$ wet sea cucumber sample so the yield is $1.3 \%$. The crude extract was used in cytotoxic test and chemical characteristics analysis.

\subsection{Cytoxicity}

Figure 1 shows an increase of cell mortality in both T47D and WiDr cell lines as the extract dose also increased in cytotoxic assessment. MTT-cytotoxic

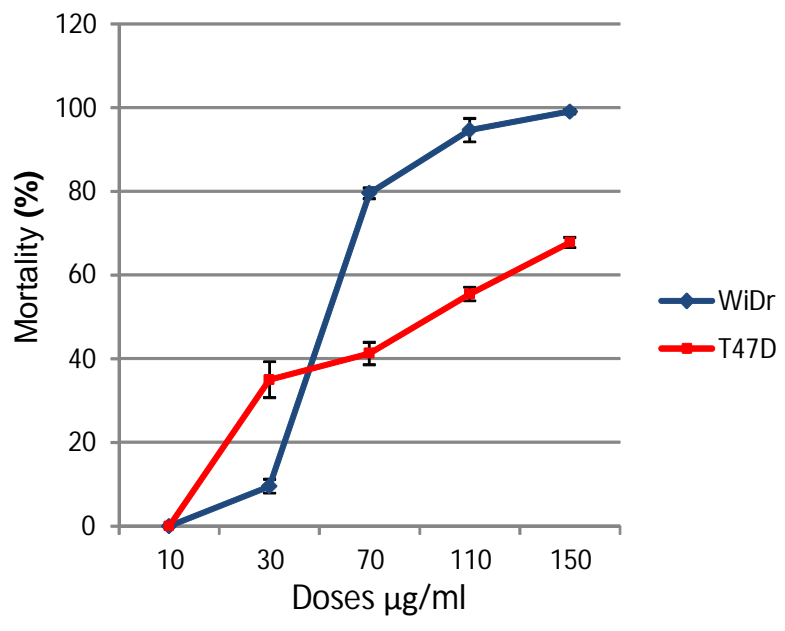

assessment is based on the formation of blue formazan crystal when MTT solution reacts with a cell line. The amount of crystal is directly proportional to the viable cell line (Ebada et al., 2008). The amount of formazan crystal in control cell (untreated cell) was more abundant than that of treated cell (Figure 1). The amount of formazan crystal was quantified spectrophotometrically right after the addition of $10 \%$ SDS. Formazan crystal concentration was directly proportional to the measured absorbance value. The lower formazan concentration is (shown by low absorbance value), the higher the cell mortality is.

The obtained cell mortality data from every extract concentration series was used to calculate $\mathrm{LC}_{50}$ value using probit analysis. The analysis showed that the methanolic extract of sea cucumber Actinopyga sp. has the $\mathrm{LC}_{50}$ value of $55.9 \mu \mathrm{g} / \mathrm{ml}$ and $87.55 \mu \mathrm{g} / \mathrm{ml}$ against WiDr and T47D cell, respectively (Table 1). Doxorubicin cytotoxic activity (positive control) against T47D cell is much higher than the methanol extract with the $L_{50}$ value of $0.295 \mu \mathrm{g} / \mathrm{ml}$. Interestingly, doxorubicin did not show such cytotoxic activity against WiDr cell. As Lou et al. (2006) stated, doxorubicin has selective activity against cancer cell line, especially to breast cancer cell line with the $\mathrm{LC}_{50}$ value of $0.3 \mu \mathrm{g} / \mathrm{ml}$.

Crude extract from natural product is considered as having strong cytotoxic activity if the $L_{50}$ value is under $30 \mathrm{mg} / \mathrm{ml}$ (Munro et al., 1987; Suffnes \& Pezzuto, 1990; Itharat et al., 2004; Chicca et al., 2008). Based on this criterion, the methanolic crude extract of sea cucumber Actinopyga sp. is not considered as having strong activity for WiDr and T47D cells.

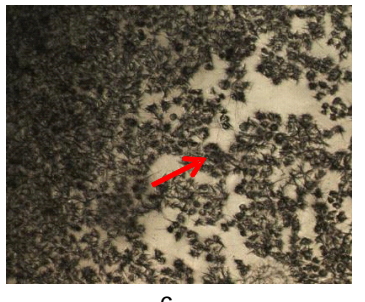

$\mathrm{C}$

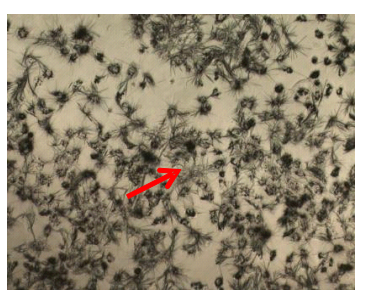

b

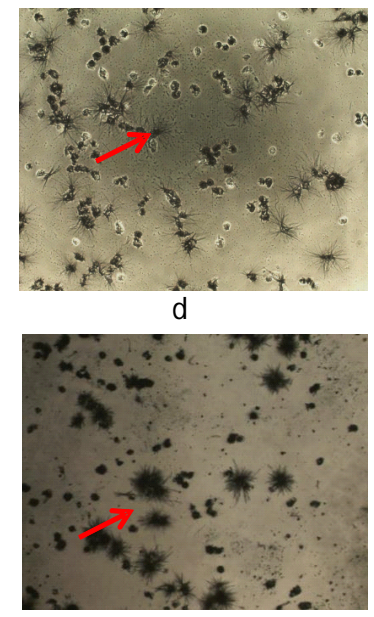

Figure 1. Mortality profile of WiDr and T47D cells after treated with Actinopyga sp. methanolic extract for 24 hours and features of formazan crystal formed as representation of viable cells (right). Notes: a (untreated WiDr cell), b (WiDr cell treated with $30 \mu \mathrm{g} / \mathrm{ml}$ ), c (T47D cell treated with $30 \mu \mathrm{g} / \mathrm{ml}$ ), d (untreated T47D cell), formazan cristal were indicated by red arrows. 
Table 1. LC $_{50}$ value of Actinopyga sp. methanolic extract compared to doxorubicin

\begin{tabular}{ccc|cc}
\hline & \multicolumn{2}{c|}{ Crude extract } & Actinopyga sp. & \multicolumn{2}{c}{ Doxorubicin } \\
\cline { 2 - 5 } $\mathrm{LC}_{50}$ & WiDr cell & T47D cell & WiDr cell & T47D cell \\
\cline { 2 - 5 }$(\mu \mathrm{g} / \mathrm{ml})$ & 55.92 & 87.55 & 162.08 & 0.295 \\
\hline
\end{tabular}

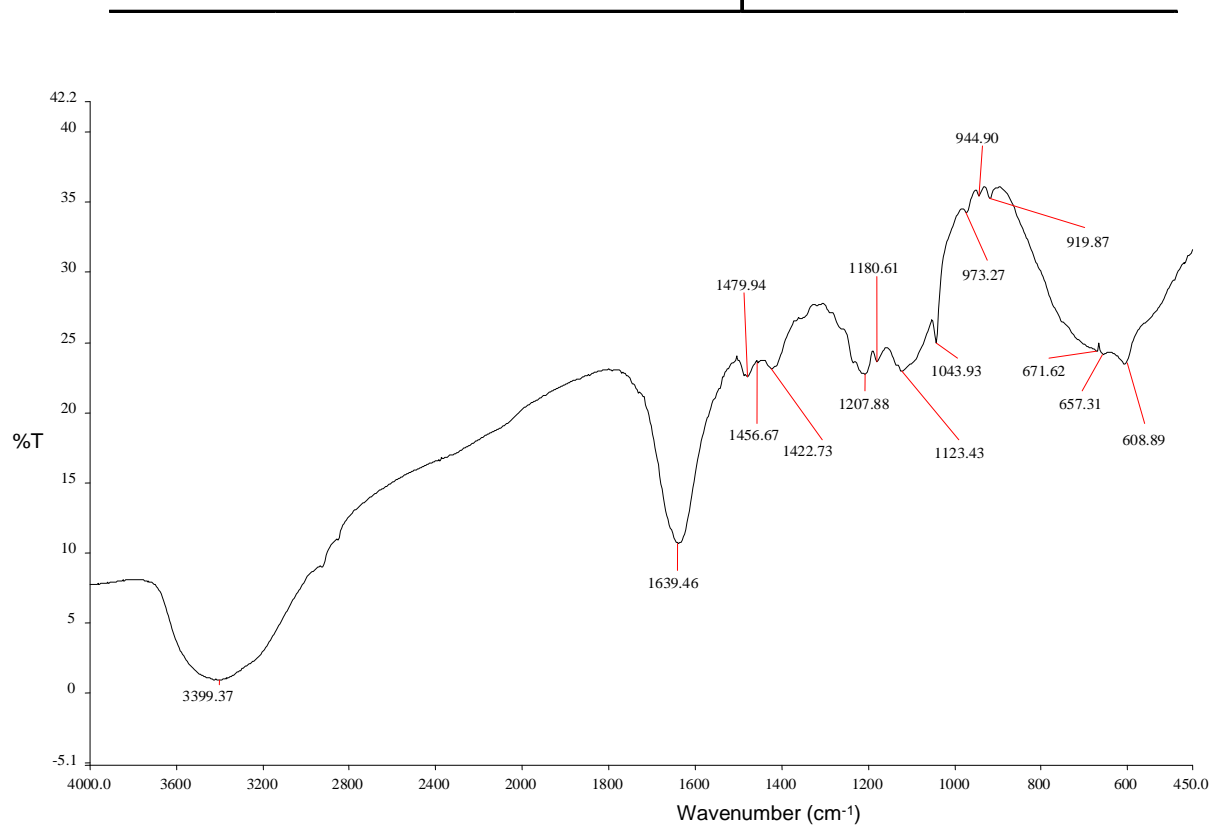

Figure 2. FTIR spectrum of Actinopyga sp. crude extract.

As shown in another study, the hexane extract of Isosticophus badionotus shows LC $_{50}$ value of 197.5 $\mu \mathrm{g} / \mathrm{ml}$ against MCF7 cell line, while the ethyl acetate extract shows strong cytotoxicity with $\mathrm{LC}_{50}$ value of $48.5 \mu \mathrm{g} / \mathrm{ml}$ (Espadas et al., 2014). Water-soluble extract from Holothuria leucospilota shows medium cytotoxicity against Wehi- 164 cell line with $\mathrm{LC}_{50}$ value of $41.3 \mu \mathrm{g} / \mathrm{ml}$ (Assarian et al., 2012). Strong cytotoxic activity is shown by the organic-soluble extract of Sticophus horrens against A549 and TE1 cell lines with $\mathrm{LC}_{50}$ value of $15.5 \mu \mathrm{g} / \mathrm{ml}$ and $4.0 \mu \mathrm{g} / \mathrm{ml}$, respectively (Althunibat et al., 2013).

\subsection{Functional Group Analysis}

Subsequently, crude extract was characterized its functional group content using FT-IR analysis. This analysis is used to identify compounds based on the nature of each compound in absorbing infrared radiation. Infrared radiation energy can excite vibrational and rotational transitions in a molecule. A molecule can vibrate in many ways, and each way is called a vibrational mode. The vibrational mode of a molecule is based on its number of atoms and its arrangement of atoms. The transitions in a molecule produce absorption peaks, which result in infrared spectra. The spectra are the characteristic of a molecule as different molecule will result in different spectra, and there is small possibility that two molecules have the same spectra.

FTIR spectra show the functional groups contained in crude extract, including alcohol, amine, alkane, alkene, carboxylic acid, nitrate, amide, sulphur, ester, and ether (Figure 2). According to Daminar \& Bajo (2013) and Aksara et al. (2013), if functional groups, such as $\mathrm{N}-\mathrm{H}, \mathrm{C}-\mathrm{N}$, and $\mathrm{C}-\mathrm{O}$, appear in an IR spectra of crude extract, it implies the presence of an alkaloid compound, which is proven by the presence of amine functional group. The peaks appeared from the IR spectra of Actinopyga sp. crude extract showed $\mathrm{N}-\mathrm{H}$ functional group at $3399.37 \mathrm{~cm}^{-1}$ and $1639.46 \mathrm{~cm}$ ${ }^{1}$, which are confirmed by C-N and C-O at 1207.88 $\mathrm{cm}^{-1} ; 1123.43 \mathrm{~cm}^{-1}$ and $1043.93 \mathrm{~cm}^{-1}$. The peaks on FT-IR spectra showed wavenumbers of $3399.37 \mathrm{~cm}^{-1}$ (O-H), $1456.67 \mathrm{~cm}^{-1}(\mathrm{C}-\mathrm{H})$ and $1207.88 \mathrm{~cm}^{-1} ; 1123.43$ $\mathrm{cm}^{-1}$, and $1043.93 \mathrm{~cm}^{-1}$ (C-O) that indicate the presence of saponin.

A similar result was also mentioned by Soltani et al. (2014). Saponins are natural glycosides attached to steroids or triterpenoids abundantly found in plants, bacteria, and marine animals (Marliana et al., 2005). 

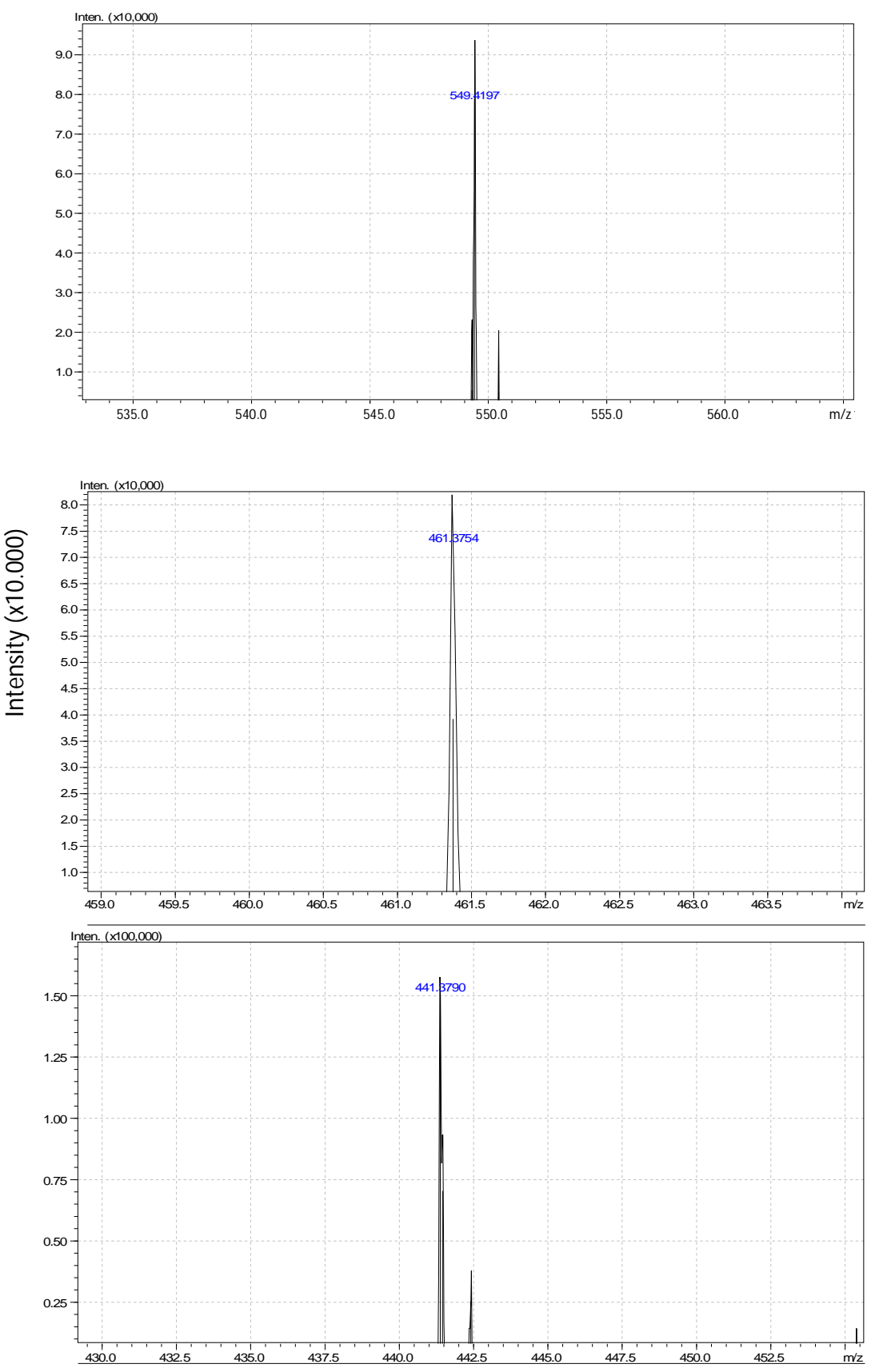

$\mathrm{m} / \mathrm{z}$

Figure 3. $\mathrm{m} / \mathrm{z}$ of three molecular ion peak $(\mathrm{IVI}+\mathrm{H})$ contained ini crude extract of Actinopyga sp.

\subsection{Mass Spectra Analysis}

Mass spectra analysis result showed that Actinopyga sp. crude extract contains steroids or terpenoids. Given the mass to charge value and molecule formula also shows that the crude extract contains fatty acids, phenols, alkaloids, etc. However, mass spectra analysis will only focus on saponin, which is dominant in sea cucumber. Ion mass peaks of steroids from crude extract are shown in Figure 3.
Based on LC/MS software calculation, the molecular ion peak of $\mathrm{m} / \mathrm{z} 549.419$ has molecular formula of $\mathrm{C}_{37} \mathrm{H}_{56} \mathrm{O}_{3}$. This molecular ion is fitted with a triterpenoid benzyl compound of (32)-3-hydroxylupan28-oate or betulinic acid (compound 1). This compound's known activities are anti- HIV (Lan et al., 2011) and human melanoma inhibitor via apoptosis induction (Pisha et al., 1995; Schmidt et al., 1997). Another molecular ion peak of $\mathrm{m} / \mathrm{z} 549.419$ is fitted to compound (8R,9S,10S,13R,14S)-10,13-Dimethyl- 

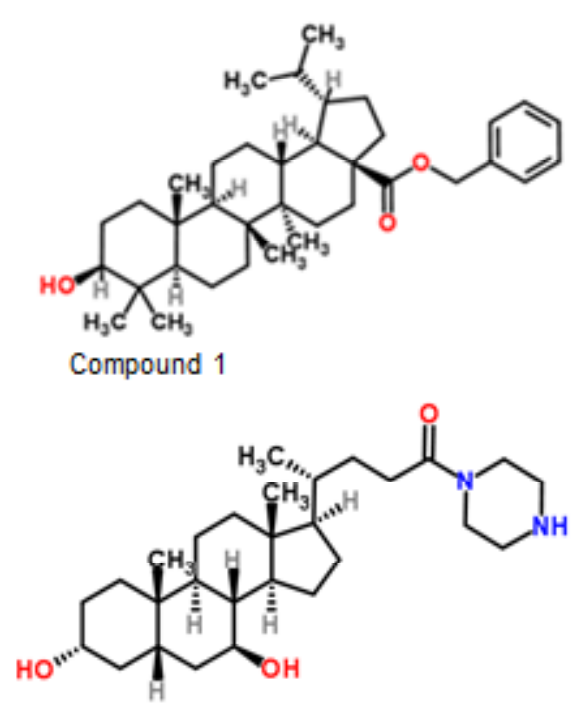

Compound 3
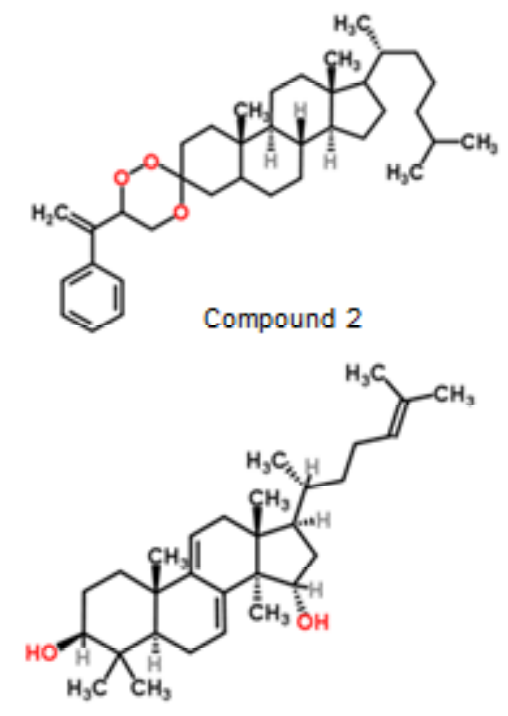

Compound 4

Figure 4. Compounds that had been found in Actinopyga sp. crude extract.

17-[(2R)-6-methyl-2-heptanyl]-6'-(1-phenylvinyl) hexadecahydrospiro [cyclopenta[a] phenanthrene-3,3'$[1,2,4]$ trioxane] (compound 2). This steroid's-activity has been known as antimalaria (Singh et al., 2007). An alkaloid attached to steroid was also detected at molecular ion peak of $\mathrm{m} / \mathrm{z} 461.3754$ and molecular formula of $\mathrm{C}_{28} \mathrm{H}_{48} \mathrm{~N}_{2} \mathrm{O}_{3}$. This compound is known as (3á,5â,7â)-3,7-Dihydroxy-24-(1-piperazinyl)cholan-24one (ursodeoxycholic acid) (compound 3 ). Sharma et al. (2011) stated the activity of this compound as liver anti-inflammation. Another steroid with known activity as alpha-receptor was also detected as (3â,15á)Lanosta-7,9(11),24-triene-3,15-diol, which has $\mathrm{m} / \mathrm{z}$ ratio of 441.8390 and molecular formula of $\mathrm{C}_{30} \mathrm{H}_{48} \mathrm{O}_{2}$ (compound 4). This compound has important role in cholesterol homeostasis (Jayasuriya et al., 2005). All of the detected compounds are presented in Figure 4.

Sea cucumbers are rich in saponin marine animals. Saponins are glycosides that consist of polycyclic aglycones, which are steroids or triterpenoids attached to one or more sugar side chains. Triterpenoid saponins consist of aglycones that are composed of 30 carbon atoms (C30), while steroid saponins consist of aglycones that are composed of 27 carbon atoms (C27) (Bahrami et al., 2014). Glycoside saponins are known as self-defense chemical in sea cucumber. Studies show that triterpen glycoside has anticancer activity (Kaswandi et al., 2004; Inayah et al., 2012). According to Zhang et al. (2008), sea cucumber Actinopyga sp. contains two sulphated triterpen glycoside compounds, i.e. lecanorosides A and B, which are capable of countering human cancer cell. On the contrary, Dyck et al. (2010) stated that this type of compounds are very powerful toxic.

Saponins are a group of the largest and most classes compounds that have been isolated from sea cucumber. Saponins are produced by sea cucumbers as a form of defense mechanism chemical in nature. Moreover, saponins are also believed to have biological effects, including antifungal, cytotoxic against tumor cells, hemolysis, and anticancer (Li et al., 2013). Saponins in sea cucumbers have been classified properly as anticancer agents. The first anticancer compound derived from sea cucumber glycosides was holothurin, a glycoside from Actinopyga agassizi, in 1952 by Nigrelli. Holothurin A can inhibit the growth of bone cancer cells (Li et al., 2013; Aminin et al., 2015). A few years later, other types of saponins have been identified from sea cucumber genus Actinopyga, namely holothurin A2; B; B1; B2; B3; B4, fuscocineroside $B ; C$, and 24-dehydroholothurin $A 2$; B1 (Caulier et al., 2011).

\section{Conclusion}

The methanolic extract of sea cucumber Actinopyga sp. has a medium cytotoxic activity against WiDr and T47D cell lines with $L_{50}$ value of 55.93 and $87.55 \mu \mathrm{g} / \mathrm{ml}$, respectively. Functional groups analysis showed the presence of hydroxyl, amine, carboxylic acid, nitrate, amide, sulphur, ester, and ether. The mass spectra of methanolic crude extract showed the presence of steroids compound. 


\section{Acknowledgment}

This research was funded by the Ministry of Marine Affairs and Fisheries of Indonesia in 2015. We thank Ms. Sri Iswani for her support on FTIR and LC/MS analysis.

\section{References}

Aksara, R., Weny, J.A., \& Alio, L. (2013). Identifikasi senyawa alkaloid dari ekstrak metanol kulit batang mangga (Mangifera indica L). Jurnal Entropi, 8(1), 514-510.

Albuntana, A., Yasman \& Wardhana, W. (2011). Toxicity test of extracts of the four sea cucumber (family Holothuriidae) from East Penjaliran Island, Seribu Island, Jakarta based on the brine shrimp lethality test (BSLT). Jurnal IImu dan Teknologi Kelautan Tropis, 3(1), 65-72.

Althunibat, O., Ridzwan, B., Taher, M., Daud, J., Ichwan, S.J.A., \& Qaralleh, H. (2013). Antioxidant and cytotoxic properties of two sea cucumbers, Holothuria edulis lesson and Stichopus horrens Selenka. Acta Biologica Hungarica, 64(1), 10-20.

Aminin, A. L., Menchinskaya, E.S., Pisliagin, E.A., Silchenko, A.S. Avilov, S.A \& Kalinin, V.I. (2015). Anticancer activity of sea cucumber triterpene glycosides. Marine Drugs, 13, 1202-1223.

Assarian, M., Rakhshan, A., Khodadi, A., Adibpour, N., \& Rezaee, S. (2012). Evaluation of cytotoxicity of two Persian Gulf sea cucumber species extracts on K562 and Wehi-164 cell lines and blood granulocyte cells. Research in Pharmaceutical Sciences, 7(5), S112, Proceeding of $13^{\text {th }}$ Iranian Pharmaceutical Sciences Congress.

Bahrami, Y., Zhang, W., Chataway, T. \& Franco, C. (2014). Structural elucidation of novel saponins in the sea cucumber Holothuria lessoni. Marine Drugs, 12, 44394473.

Bhakuni, D.S \& Rawat, D.S. (2005). Bioactive Marine Natural Product. Springer. New York, USA. 1-379.

Blunden, G. (2001). Biologically active compounds from marine organisms. Phytotherapy Research., 15, 8994.

Bordbar, S., Anwar, F. \& Saari, N. (2011). High value components and bioactives from sea cucumbers for functional food: A Review. Marine Drugs, 9, 17611805.

Butler, M.S. (2004). The role of natural product chemistry in drug discovery. Journal Natural Product, 67(12), 41-53.

Caulier, G., Dyck, S.V, Gerbaux, P., Eeckhaut, I \& Flammang, P. (2011). Review of saponin diversity in sea cucumbers belonging to the family Holothuriidae. SPC Beche-de-mer Information Bulletin, 31, 48-53.

Chatterji, A., Kassim, Z., Hassan, A., Therwath, A., \& Shaharom, F. (2010). Marine living resources in the practice of traditional medicine. Journal Coastal Environment, 1(1), 41-52.
Chicca, A., Pellati, F., Adinolfi, B., Matthias, A., Massarelli, I., Benvenuti, S., Martinotti, E., Bianucci, A.M., Bone, K., Lehman, R., \& Nieri, P. (2008). Cytotoxic activity of polyacetylenes and polyenes isolated from roots of Echinacea pallida. British Journal of Pharmacology, 153, 879-885.

Daminar, N. L. \& Bajo, L.M. (2013). Isolation and partical characterization of the most bioactive metabolite from the hexane extract of aerial part of hydrocotyle verticillat. Global Journal of science Frontier Research Chemistry, 13(2), 1-8.

Dyck, S. V., Gerbaux, P., \& Flammang, P. (2010). Qualitative and quantitative saponin contents in five sea cucumbers from the Indian Ocean. Marine Drugs, 8, 173-189.

Ebada, E.S., Edrada, R.U., Lin, W., \& Proksch, P. (2008). Methods for isolation, purification and structural elucidation of bioactive secondary metabolites from marine invertebrates. Nature Protocols, 3(12), 18201831.

Elbandy, M., Rho, J., \& Afifi, R. (2014). Analysis of saponins as bioactive zoochemicals from the marine functional food sea cucumber Bohadschia cousteaui. Europian Food Research and Technology, 10: 6.

Espadas, A.R.P., Star, M.J.V., Morales, C.R., Cardenas, A.O., Rubio, M.E.M., Deniz, L.V.L., Canche, J.C., \& Quijano, L. (2014). Invitro Cytotoxic Activity of Isostichopus badionotus, a Sea Cucumber from Yucatan Peninsula Coast. Journal of Pharmacy and Nutrition, 4, 183-186.

Fawzya, Y.N., Januar, H.I., Susilowati, R., and Chasanah, E. (2014). Chemical composition and fatty acid profile of some Indonesian sea cucumbers. Squalen Bull. of Mar. \& Fish. Postharvest \& Biotech. 10(1), 27-34

Inayah, N., Ningsih, R., \& Adi, T.K. (2012). Uji toksisitas dan identifikasi awal golongan senyawa aktif ekstrak metanol dan n-heksana teripang pasir (Holothuria scabra) kering Pantai Kenjeran Surabaya. Alchemy, 2(1), 92-100.

Itharat, A., Houghton, P.J., Eno-Amooquaye, E., Burke, P.J., Sampson, J.H., \& Raman A. (2004). Invitro cytotoxic activity of Thai medicinal plants used traditionally to treat cancer. Journal of Ethnopharmacology, 90, 33-38.

Jain, R., Sonawane, S. \& Mandrekar, N. (2008). Marine organisms: potential source for drug discovery. Current Science, 94(3), 1.

Januar, H.I., Nursid, M., and Chasanah, E. (2014). Cytotoxic saturated fatty acids from the Indonesian sea cucumber Holothuria sp. Squalen Bull. of Mar. \& Fish. Postharvest \& Biotech., 9(1), $11-25$.

Jayasuriya, H., et al. (2005). Diterpenoid, steroid, and triterpenoid agonists of liver $X$ receptors from diversified terrestrial plants and marine sources. Journal of Natural Products, 68,1247-1252.

Kaswandi, M. A., Hing, H.L., Sahalan, A.Z., Farah, F., Ridzwan, B.H., Samsudin, M.W., Yasin, M.S.M., \& Manaf, A.A. (2004). Saponin from sea cucumber Stichopus badionotus sluiter as potential cytotoxic 
agent on CEM-SS T-lymphoblastic cell. Journal Microscopy Social Thailand. 18 (1), 79-84.

KEMENKES RI. (2014). Hilangkan Mitos Tentang Kanker. http://www.depkes.go.id /article/print/201407070001/ hilangkan-mitos-tentang-kanker.html. Diakses pada tanggal 3 April 2015.

Lan, P., Chen, W.N., Huang, Z.J., Sun, P.H., \& Chen, W.M. (2011). Understanding the structure-activity relationship of betulinic acid derivatives as anti-HIV1 agents by using 3D-QSAR and docking. Journal of Molecular Modeling, 17(7), 1643-1659.

Leal, M., Costa, C., Madeira, C., Brandao, A., Puga, J., \& Calado, R. (2012). Bioprospecting of marine invertebrates for new natural products-a chemical and zoogeographical perspective. Molecules, 17, 9842-9854

Li, Y. X., Himaya, S.W.A., \& Kim, S.K. (2013). Triterpenoids of marine origin as anti-cancer agents. Molecules, 18, 7886-7909.

Liu, X., Zhenliang, S., Miansong, Z., Xiumei, M., Xuekui, X., Wenpeg, Y., Feng, X., \& Changheng, L. (2012). Antioxidant and antihyperlipidemic activities of polysaccharides from sea cucumber Apostichopus japonicas. Carbohydrate Polymers, 90(4), 16641670.

Lou, P. J., Lai, P.S. Shieh, M.J., Robert, A.J.M., Berg, K., \& Brown, S.G. (2006). Reversal of doxorubicin resistance in breast cancer cells by potochemical internalization. International Journal Cancer, 119, 2692-2698.

Marliana, S. D., Suryanti, V. \& Suyono. (2005). Skrining fitokimia dan analisis kromatografi lapis tipis komponen kimia buah labu siam (Sechium edule Jacq. Swartz.) dalam ekstrak metanol. Biofarmasi, 3(1), 26-31 .

Munro, M.H.G., Luibrand, R.T., \& Blunt, J.W. (1987). The Search for Antiviral and Anticancer Compounds from Marine Organism. In : Scheur, P. Bioaorganic Marine Chemistry, Vol. 1. Springer-Verlag, Berlin. 615 pp.

Murti, Y. \& Agrawal, T. (2010). Marine derived pharmaceuticals development of natural health products from marine biodiversity. International Journal of Chemical Technology Research, 2(4), 2198-2217.

Pringganies, D. (2013). Antibacterial activity of sea cucumbers harvested from Karimunjawa. Squalen Bull. of Mar. \& Fish. Postharvest \& Biotech. 8(2), 87 94.

Pisha, E., Chai, H., \& Lee, I.S. 1995. Discovery of betulinic acid as a selective inhibitor of human melanoma that functions by induction of apoptosis. Nature Medicine, 1(10), 1046-1051.

Rakesh, P., Charmi, P., \& Rajesh, K.S. (2014). Quantitative analytical applications of FTIR spectroscopy in pharmaceutical and allied areas. Journal of Advanced Pharmacy Education and Research, 4(2), 147-157
Salazar, M. F., Vasquez, E.O., Canul, R.R., \& Castillo, L.O. (2013). Antimicrobial activity of aqueous extracts of sea cucumber (Isostichopus badionotus) from the coast of Yucatan, Mexico. African Journal of Microbiology Research, 7(28), 3621-3626.

Schmidt, M.L., Kuzmanoff, K.L., Ling-Indeck, L., \& Pezzuto, J.M. (1997). Betulinic acid induces apoptosis in human neuroblastoma cell lines. European Journal of Cancer, 33(12), 2007-2010.

Shahidi, F. (2009). Nutraceuticals and functional foods: Whole versus processed foods. Trends Food Science Technology, 20, 376-387.

Sharma, R., Prichard, D., Majer, F., Byrne, A.M., Kelleher, D., Long, A., \& Gilmer J.F. (2011) Ursodeoxycholic acid amides as novel glucocorticoid receptor modulators. Journal of Medicinal Chemistry, 54, 122130.

Singh, C., Sharma, U., Saxena, G., \& Puri, S.K. (2007). Orally active antimalarials: synthesis and bioevaluation of a new series of steroid-based 1,2,4trioxanes against multi-drug resistant malaria in mice. Bioorganic \& Medicinal Chemistry Letters, 17(15), 4097-4101.

Slichenko, A. S., Kalinovsky, A.I., Avilo, S.A., Andyaschenk, P.V., Dmitrenok, P.S., Yurchenko, E.A., \& Kalinin, V.I. (2012). Structures and cytotoxic properties of cucumariosides $\mathrm{H} 2, \mathrm{H} 3$, and $\mathrm{H} 4$ from the sea cucumber Eupentacta fraudatrix. Natural Product Research, 26(19), 1765-1774.

Soltani, M., Parivar, K., Baharara, J., Kerachian, M.A., \& Asili, J. (2014). Hemolytic and cytotoxic properties of saponin purified from Holothuria leucospilota sea cucumber. Reports of Biochemistry \& Molecular Biology, 3 (1), 1-8.

Suffness, M. \& Pezzuto, J.M. (1990). Assays related to cancer drug discovery. In: Hostettmann K (ed). Methods in Plant Biochemistry: Assays for Bioactivity, vol. 6. Academic Press: London. pp 71-133.

WCRF. (2012). Colorectal Cancer Statistics. www.wcrf.org/int/cancer facts figures/ dataspesificcancers/clorectal cancerstatistics. Access: 20 April 2015.

Webb, G.P. (2006). An Overview of Dietary Supplements and Functional Food. In Dietary Supplements and Functional Foods, $1^{\text {st }}$ ed. Blackwell Publishing. Oxford, UK. 1-35 pp.

Wijesinghe, W. A. J. P., Jeon, Y.J., Ramasamy, P., Wahid, M.E.A., \& Vairappan, C.S. (2013). Anticancer activity and mediation of apoptosis in human $\mathrm{HL} \times 60$ leukaemia cells by edible sea cucumber (Holothuria edulis) extract. Food Chemistry, 139(1), 326-331.

Zhang, S. L., Peng, L.L., \& Yi, Y.H. (2008). Lecanorosides $\mathrm{A}$ and $\mathrm{B}$, two new triterpene glycosides from the sea cucumbers Actinopyga lecanora. Journal of Asian Natural Product Research, 10(12), 1097-1103. 